\title{
Analysis of Water Pollution Control Laws in South Africa
}

\author{
Busi R. Nkosi \\ Kola O. Odeku \\ Faculty of Management and Law, University of Limpopo, Turfloop, South Africa
}

Doi:10.5901/mjss.2014.v5n23p2572

\begin{abstract}
This paper examines regulatory interventions to prevent, control and curb water pollution by considering various environmental laws principles that are in place to checkmate the activities of polluters. It looks at the extent at which the regulatory institutions have stood up to the challenge of tackling water pollution and remedial actions taken. As courts are known to be playing proactive roles in enforcing water pollution control laws, the paper considers some of the court cases and applied their salient decisions to the discourse, especially with regard to holding polluters accountable. This is to compel to the polluters to remedy the pollution caused as a result of irresponsible or reckless behaviour. The paper argues that even though some polluters seek to contribute to the economic growth and development through their industrial activities, they are often the main source of water pollution in the country. Against the backdrop of this, it is emphasised that there is need to maintain the balance between economic growth and development and at the same time ensure that water is not polluted in order to preserve and guarantee sustainable use of water for both domestic and industrial activities.
\end{abstract}

Keywords: Regulatory interventions, Pollution, Water, Culprits, Remedies

\section{Introduction}

South Africa is a predominantly semi-arid country; it has an average rainfall of $450 \mathrm{~mm}$ per annum compared to the world average of $860 \mathrm{~mm}$ per annum (Otieno and Ochieng, 2007). As a result of this, South Africa's water resources are scarce and limited (Postel, 2000). Water as an important resource is fundamental to all forms of life as human beings, animals and plants need water regularly for their growth and well- being ( Falkenmark and Rockström, 2004). There are different categories of water resources; these include surface water, ground water, water impoundments and precipitation. Surface water includes all water found on the surface of the earth such as lakes, dams, wetlands and rivers (Ritter et al. 2002). Groundwater refers to water that is beneath the surface of the earth (Aller et al. 1987) like the water in wells are got from ground water (Brunner et al. 2011). Water impoundment occurs when a body of water is created or stored by impoundment structures, such as dams, dikes, and levees while precipitation is any form of water falling from the sky, for example rain, snow, hail and drizzle (Hunt, 2007). Water pollution occurs when water is contaminated. Water can be polluted by chemical, biological or physical changes in the water (Hogan, 2013).

Consequently, the polluted water then becomes unsuitable for human consumption as it can be lethal; it is also a threat to the flora and fauna (Annenberg, 2010). Most diseases in the world are related to water pollution and poor sanitation ( Ashbolt, 2004). To break the cycle of diseases, there must be improvements in the quality of water that people use (Batterman et al. 2009). This was evident in a recent case in Carolina, Mpumalanga, South Africa, where the water was found to be contaminated by acid mine seepage and many people were reported to be suffering from stomach ailments (Blaine, 2012).

In an unreported matter between Federation for Sustainable Environment and Others versus Minister of Water Affairs and Others case no:( 35672/12) (2012)ZAGPPHC 140, the North Gauteng High Court in South Africa made an order compelling the Gert Sibande Municipality to provide temporary potable water to the residents of Silobela, Caro Park and Carolina within 72 hours. The order also directed the municipality to engage actively and meaningfully with the residents regarding the steps that are being taken to ensure that potable water can once again be provided through the water supply services. It is evident that the courts are not afraid to hold institutions and structures of government that are responsible for ensuring the fulfilments of people's human rights accountable to their obligation (Federation for Sustainable Environment and Others v Minister of Water Affairs and others case no: (35672/12) (2012) ZAGPPHC 140). Water pollution has ghastly consequences on human health as well as on the environment ( Davis, 2003). A polluted river can negatively affect the flora and fauna. These negative effects could take years to rectify (Davis, 2003). Most often than 
not the water pollution and its effects cannot be fully remedied to its previous state thus, prevention of pollution becomes a better option than restoration (Dales, 2002).

In South Africa, it was estimated that "between 12 and 14 million South Africans do not have access to safe water and over 20 million are without sanitation" (Glazewski, 2005). As the population continue to increase, water pollution problems and challenges will also increase (Vörösmarty et al. 2009). Implementable and enforceable regulatory interventions and the administrative wills by the government institutions are powerful tools that can be optimally used to regulate and control the conduct of people to ensure that they maintain and conserve clean water (Manual, 2008).

As a rule, one would look towards the polluter and the user pays principle which holds that polluters and users of natural resources bear the full responsibility of their impact on any resource (Grossman, 2006). Economic regulatory intervention is aimed at impacting the behaviour by encouraging and inducing behaviour that puts less strain on the environment (Mason et al. 2007). Example of attempts to apply this principle includes financial charges for industrial waste discharges and special taxes on pesticides (Helmer et al. 1997). The shortcoming of the application of this principle is that sometimes, the polluter is unknown and as such no one can be held responsible (Helmer et al. 1997).

Consequently, the overall aim of this paper is to ensure that there is a zero tolerance to water pollution, however if it happens, prompt remedial measures and appropriate sanctions should be applied in order to remedy the damage done and restore good and clean water by invoking the laws and holding polluters accountable. This will serve as a deterrent to ambitious would-be polluters to think twice before going on the voyage of pollution.

\section{Literature Review}

In general, South Africa has a limited supply of water and the quality of this water is being threatened by pollution and the destruction of river catchments (Oberholster, 2008). As the population grows so does the increase in water consumption; such an increase in usage brings about an escalation in pollution, catchment destruction and a decrease in the quality of water reservoirs and the natural environment (Malmqvist and Rundle, 2002). Zero tolerance to water pollution will ensure that the little water that is available is used for the betterment of the people (Kirda and Kanber, 1999). Access to clean water is a right of every person, but the growth in industrialisation has increased the amount of waste pollution especially water pollution, which is ultimately making it difficult for people to enjoy this right (Scanlon, 2004). The health hazard that polluted water poses to human beings, animals and other living things warrants the need to impose water control measures which can reduce pollution to such an extent where very little pollutants are discharged into water (Ganoulis, 2008).

There is a saying that goes thus "prevention is better than cure" (Schaeffer, 2012), so the question is why wait for the water to be polluted first then embark on cleaning up measures? It is more difficult and costly to clean polluted water than to maintain clean and safe water. The best option would be to prevent water pollution before it occurs rather than attempting to solve the problem after it had occurred (Drinan and Spellman, 2012).

Pollution is defined as "something in the wrong place" (Jeffries and Mills, 1990). This definition conveys the important fact that any substance can be considered a pollutant, if it is present in concentrations exceeding those normally found in the system. Mason (1990) defined pollution as "the introduction, by humans, into the environment of substances or energy liable to cause hazard to human health, harm to living resources and ecological systems, damage to structure or amenity or interference with legitimate use of the environment." The definitions of pollution by the two writers give a clear indication that pollution only occurs when foreign objects are present in water, be it in ground water or surface water.

In Southern parts of Africa, the quality of water supplies once taken for granted, is becoming the focus of increasing concern because, according to Moyo and Mtetwa (1990) "the solid, liquid and particulate waste that result from urbanisation and economic activities are contaminating air, soil and water." They also observed that "the main sources of water pollution are untreated or partially treated effluents from municipal, industrial and mining waste water discharges. Professor Moyo in his discussions went further to say that degradation of river water quality has increased the health risks of those who consume the water from the region's water resources."

The problem of water pollution is not only prevalent in South Africa but also in many parts of the world. In India, there is a general believe that the Ganga River is clean and holy, however, the study conducted on the Ganga River by Sharma in (1997) revealed that there were "over use, abuse and pollution of the river; the towns along its banks are said to be contributing to the pollution of the river." Sharma characterises the sources of the pollution of the river to be domestic and industrial waste: solid garbage thrown directly into the river, non-point sources of pollution such as agricultural run-off containing residues of pesticides and fertilisers, animal carcases and half burned and unburned human corpses thrown into the river, defecation on the banks by the low income people, mass bathing and ritualistic 
practices.

In terms of the (The Convention for the Protection of Natural Resources and Environment of the South Pacific Region, 1986, states are obliged to take all the appropriate measures to prevent, reduce and control pollution from any source, and to ensure sound environmental management and the development of natural resources using the best practical measures. Pursuant to this, the use of economic instruments is considered a useful strategy for regulation by government, in those instances where regulation pertains to the protection of public goods, such as water resources (Bakker, 2007). The polluter pays principle plays a central role in economic instruments to ensure clean water. To this end, De Sadeleer (2002) observes that "the polluter pays principle has successfully been invoked to address distortion or competition (objective of economic integration) as a preventive instrument to establish the internalisation of chronic pollution (instrument of prevention ex ante), and finally to justify the adoption of fiscal measures. It is generally accepted that the polluter pays principle implies setting up a system of charges by which polluters help finance public policy to protect the environment"

It must be pointed out that not all users of water resources are polluters; only those users who discharge substances into water in an unacceptable manner or contrary to the laws are liable to bear the cost of pollution and the cost of remedying the effects of pollution (Kettlewell, 1992). The user pay principle means that a payment for discharge of pollutant into environmental and based upon approximate pollutant loading is mandated to be paid by the polluter (Nash, 2000). This means that money will be paid to the government for the provision of environmental public goods or services, in this instance services and goods relating to use of water resources will be done within their carrying capacity ( Kotze and Bosman, 2006).

\section{What is Water Pollution?}

Water pollution is defined in the National Water Act of 1998 as "the direct or indirect alteration of the physical, chemical or biological properties of a water resource so as to make it less fit for any beneficial purpose of which it may reasonably be expected to be used, or harmful or potentially harmful to the welfare, health or safety of human beings, to any aquatic or non- aquatic organisms to the resource quality or to the property." The Act stipulates that watercourse means a river or spring, a natural channel in which water flows regularly or intermittently; a wetland, lake or dam into which water flows and any collection of water which the Minister may by notice in the Gazette declare to be a watercourse, and a reference to a watercourse includes where relevant, its bed and banks. Water resource includes a watercourse, surface water, estuary or aquifer. There are different categories of water resources including surface water, ground water, water impoundments and precipitation. Water pollution occurs when water is contaminated and pollutants are discharged directly or indirectly into those water bodies without adequate treatment to remove harmful compounds (Chapman, 1996). This affects plants and organisms living in this water. There is a need to impose water pollution control measures to achieve the safety of water.

\section{Significance of Water Pollution Control}

Water is the source of life for human beings. Animals and plants also need water for growth (Postel and Richter, 2003). The scourge of water pollution in South Africa due to various reasons is of great concern and if left unattended will have dire consequences (Ewart, 2011). Uncontrolled water pollution results in health hazards to human beings, animals and other living things ( Harte et al 1991).

In terms of the South African Constitution, the state as a custodian of all natural resources has a duty to ensure that water as a scarce resource is preserved for the present and future generations (Kidd, 2009). Legislative measures are needed to ensure that this preservation prevails (Feris, 2012). Legislation imposes measure on the preservation of natural resources such as a permit and condition that must be respected by the holder of such permit (Stein, 2005). Failure to observe the condition of the permit is punishable by law for both corporates and human beings (Francis, 2005).

Most environmental crimes are caused not by deliberate intentions or negligence, but by poor or ineffective management systems (Kanamugire, 2008). Public education is important in ensuring that water pollution does not take place ( Tran et al. 2002). Authorities must be strict in ensuring compliance with permits and prevention of water pollution (Irwin, 1992).

Tackling the problem of water pollution should be the responsibility of everybody as clean and safe water is necessary for all (Hines, 1966). In the case of flagrant violation of the water law, remedial action should be taken and restitution should take precedence before any other sanction kicks in (UNRISD, 2003). 


\section{Consequences of Water Pollution}

Polluted water is unsuitable for any human need and is a threat to flora and fauna ( Palmer and Richardson, 2009). The consumption of polluted water can result in ill health and may even be lethal ( Järup, 2003). This may materialise when water-borne diseases such as cholera, caused by polluted or contaminated water affect people ( Bond and Desai, 2011). This was evident when the applicants in the case of Federation for Sustainable Environment and Others versus Minister of Water Affairs and Others case no:( 35672/12) (2012) ZAGPPHC 140 stated above approached the court by way of urgency in seeking an order declaring that the failure of the respondents to provide access to effective/reliable potable water for more than seven full days, as prescribed by regulations $3(b)$ of the regulations relating to compulsory national standards and measures to conserve water to the residents of Silobela Caro park and Carolina Town in Carolina Mpumalanga is unlawful (Federation for Sustainable Environment and Others v Minister of Water Affairs and Others (35672/12) [2012] ZAGPPHC 128( 10 July2012). This situation emanated from the fact that the water supply in Silobela Carolina was contaminated by "acid mine water" to an extent that it was not healthy for both human and animal consumption. In an attempt to alleviate the plight of the community, water tanks were brought to supply water to the community. However, due to the poor management of the water tanks, the water supply in general was inadequate. Some of the residents had to walk long distances to access the potable water from the tanks.

Polluted river may fatally affect flora and fauna and they may take years to recover. People need to maintain and conserve clean water. Legislation is required to regulate the conduct of people maintain clean water (Humphreys, 1989). Pollution of the environment by mines that dump wastes in water reservoirs has dire effects on human beings like birth defects and contamination of land that prevents crops from growing. (Hollar, 2011). The Cuyahoga River in Cleveland, Ohio which served as a dump site for industries was so contaminated by chemicals that it caught fire in 1969 (Shiva, 2002). This demonstrates the dangers of uncontrolled pollution of water. In order to minimise the consequences of water pollution, sanctions and penalties need to be created and enforced against for polluters.

\section{Regulatory Frameworks on Water Pollution}

Although provisions controlling water pollution appear in statutory law, these must be seen in the context of common law, particularly nuisance and neighbour law (Glazewski, 2005). In the case of Rainbow Chicken Farm (Pty) Ltd v Mediterranean Woollen Mills (Pty) Ltd 1963(1)SA $201 \mathrm{~N}$, the court held that the producer of the effluent, apart from the statutory duties imposed upon him by section 21(1) and (2) of the water Act 1956, owes a common law duty of care towards others. Where the producer of effluent discharges it from its factory into a public stream and such effluent pollutes it, both in the sense that it does not conform to the standards laid down in terms of the statute and that it amount to pollution at common law, an injured third party may elect whether to proceed against the producer for breach of the statutory duties or under the common law. The applicant obtained an interdict to stop the respondent from discharging effluent from its factory into the river. The significance of this case is that it creates a duty of care for the producer of the effluent to prevent it from causing harm to others. This is crucial as everyone is expected to control their behaviour and refrain themselves from harming others.

Until recently in South Africa, water law was developed inappropriately, as access to water was to the detriment of the majority of the population ( Kidd, 2009). The state had the right to allocate water. The Water Act 54/56 which was passed in 1956 was enacted during the apartheid era and did not replace the riparian right system doctrine developed in South African common law largely as a result of the influence of the English Law (Albert et al. 2014). The system gave the riparian owner the right to use the water resource and all surplus water with respect to agricultural and industrial purposes. A landowner who owns land that physically touches a river, stream, pond or lake had an equal right to the use of water from that source. This was evident in the case of Retief versus Louw, the Supreme Court of the Cape of Good Hope, Judgement of 12 January 1856 (1874) 4 Buch 165, the upstream owner diverted the whole of the stream's summer flow and thus deprived the downstream owner of water for drinking purposes and irrigation. The court held that for perennial streams running over several adjoining land parcels, each landowner has a common right in the use of water. The use of the water at every stage of its exercise by any one of the proprietors is however limited by a consideration of rights of other proprietors. This led to the majority of Black South Africans being restricted in their access to water because most were not land owners. The Act made a distinction between private and public water. Private water is defined as "all water which rises and or falls naturally on any land or naturally drains or is led onto one or more pieces of land which are the subjects of separate original grants but is not capable of common use for irrigation purposes." This gave the owner in whose land private water was found exclusive use and enjoyment of such water provided he/she does not pollute it. The Water Act 54/56 made a distinction between private and public water. Public water is defined in the act 
as "any water flowing or found in or derived from the bed of a public stream whether visible or not". Public water is defined in the Act as "any water flowing or found in or derived from the bed of a public stream whether visible or not." The right to use public water was divided into three categories namely: agricultural purposes, urban purposes and industrial purposes provided that such usage was beneficial and did not amount to wastage. After 1994, when the new dispensation came into effect, an obligation was placed on the state by the Constitution to ensure that water as a scarce resource is preserved for the present and future generations; therefore the state has a duty to take legislative and other measures to protect the environment (Kotzé, 2010). Clean and clear water links closely with an environment that is not harmful and prevents pollution (Kreamer and Usher, 2010). Water falls within the exclusive national competence and the state is the custodian of the nation's water (Stein, 2004). The Department of Water Affairs is the control body of water. Section 24 of the constitution provides that "everyone has the right to - a) an environment that is not harmful to their health or well - being and $b$ ) to have the environment protected for the benefit of present and future generations through reasonable legislative and other measures that, i. prevents pollution and ecological degradation; ii. Promote conservation; and iii. Secure ecological sustainable development and use of natural resources while promoting justifiable economic and social development."

The right to water is provided for in section 27 of the constitution that everyone has the right to have access to sufficient water and that the state must take reasonable legislative and other measures within its available resources to achieve the progressive realisation of each of these rights. The new water legislation centres around these two rights mentioned above.

The National Water Act of 1998 (NWA) was promulgated to regulate the manner in which individuals obtain clean water and provides for just and equitable utilization of water resources (Burchi, 2012). The Act is based on the constitutional right of access to water in terms of Section 27(1)(a) and (2), it recognises that water is a natural resource and belongs to all people. Sustainability and equity are identified as central guiding principles in the protection, use and management of water resources. This guiding principle recognizes; the basic human needs of present and future generations, the need to protect water resources, the need to share some water resources with other countries and the need to promote social and economic development through the use of water.

One of the objectives of the NWA is to reduce and prevent pollution and degradation of water resources as articulated in Section 2(h) of the Act. Section 19 deals with prevention and remedying effects of pollution. It provides that an owner of land, a person in control of land or a person who occupies or use the land on which an activity or process is, or was performed or undertaken as any other situation exists, which caused, or is likely to cause pollution of a water resource must take all reasonable measures to prevent any such pollution from occurring, continuing or recurring by virtue of Section 19(1).

The reasonable measures that may be taken include measures to cease, modify or control any act or process causing the pollution, to comply with any prescribed waste standard or management practice, to contain or prevent the movement of pollutants, to eliminate any source of pollution, to remedy the effect of the pollution and of any disturbance to the bed or banks of a water course in terms of Section 19 (2) (a-f).

Any person who fails to take reasonable measures required may be directed by a catchment management agency to commence taking specific measures before a given date prescribed in terms of Section 19(3) (a-c). If a person fails to comply, or complies inadequately with any given directive, the catchment management agency may take the measures it considers necessary to remedy the situation by virtue of Section 19(4).

In terms of section 19 (4) and (5) of the NWA, the catchment management agency has a duty to recover all costs incurred if a person has failed to comply or complied inadequately with the directive given in terms of sub section (3) as a result of taking the necessary and/or reasonable measures to remedy the situation individually and/or jointly. These include any person who is or was responsible for, or who directly or indirectly contributed to the pollution or potential pollution. This will include the owner of the land at the time when the pollution or potential for pollution occurred or the owner's successor in title. They also include the person in control of the land or any person who has a right to use the land at the time when the activity or the process is or was performed or undertaken or the situation came about and people who negligently failed to prevent the activity or the process being performed or undertaken or the situation from coming about as laid out in Section 19(5)(a-d) Act 38/98.

In practice, environmental officers mostly first perform necessary activities to prevent water pollution and collect claims from the responsible person later. It makes sense to prevent further pollution of the water than having to pursue the perpetrators at that point in time. This is because the state has a duty to protect the water for the present and future generations in terms of the Constitution.

The interpretation of section 19 of the NWA was elucidated by the court in the case of Minister of Water Affairs and Forestry Vs Stilfontein Gold Mining Company and Others (7655/55,7655/55) [2006] ZAGPHC 47 (15 May2006). The 
applicant issued directives in terms of section 19(3). The applicant was concerned that mining activities in the KOSH area may cause pollution to valuable water resources. The directives were aimed at ensuring that the risk of water pollution as a result of mining activities did not materialise. The mines were not disputing that their activities could potentially cause pollution to water resources and that management of underground water was essential to continued safe mining operations. The mines are Stilfontein, Buffelsfontein, Hartebeesfontein, Harmony and AngloGold. The first three are the northern most shallowest and defunct. They closed their mining operations years ago, but they continued dewatering ground-water from their shafts. The ultimate dispute followed the liquidation of one of the companies, Buffelsfontein and the consequent threat of dewatering of that mine. The purpose of dewatering was to extract water at the highest possible level before it becomes polluted and to prevent the deeper mines from becoming flooded.

As a result, the Regional Director issued two directives in terms of section 19(3) of the NMA. The directives required Harmony to pump water from its shafts and in addition, to share in the cost of pumping water from disused shafts. Harmony was aggrieved by the latter aspect of the directive and challenged it in the High Court on the basis that Section 19 did not authorise it. The court held that inadequate dewatering at the northern west mine would result in the unremoved water reaching the appellant's mine and becoming polluted and the matter therefore fall within the provision of section 19 of the Act duly enabling the directive in question. The mines appealed against the decision and argued that the measures referred to in section 19(1) could not lawfully be taken beyond the boundaries of its land. The Supreme Court of Appeal also dismissed the appeal by the mines and upheld the decision of the court aqua.

The infiltration of acid mine drainage (acid mine drainage is highly acidic water flowing from old mining areas. This water often contains high concentrations of metals, sulphides and salt) into South Africa's surface and groundwater system is wreaking havoc and the effects are both long term and far reaching. In August 2002, acid mine drainage started to gradually flow out of defunct underground mines in the West Rand near Krugersdorp polluting surface waters. In total, an estimated 10 billion rand will be required to treat acid mine drainage via the neutralisation and desalination of the water, this will provide about 150 million litres of potable quality standard water. According to the Department of Water Affairs, the government and mines will assume a portion of the cost with the bulk of it falling to consumers who were never a part of the pollution in the first instance. Section 19(3) vest certain powers in a catchment management agency however, section 72(1) provides that the powers of a catchment management agency vest in the Minister of Water Affairs in areas such as the KOSH area for which catchment management agency has not been established is delegated to the Regional Director. In issuing the directives, the Regional Director acted under the said delegation.

The court held that "the legislature intended by the term reasonable measures to lay down a flexible test dependent on the circumstances of each case. This was a reasonable anti-pollution measure to prevent ground water from the defunct mines reaching the active ones. The constitutional and statutory anti-pollution objectives would be obstructed if the measures required of the person referred to in section 19(1) were limited to measures on the land mentioned in the sub-section. If the choice were between an interpretation confining preventative measures to one's own land and a construction without that limitation, it is clear that the latter interpretation would be consistent with the purpose of the Constitution and the former not." The appeal was dismissed with cost. As such, the court endorsed the polluter and user pay principle. In this instance the pollution was temporal in nature and the court was not asked to address the thorny issue of acid mine drainage related to historical pollution.

The NWA provides for the control of emergency incidents such as any incident or accident on which a substance pollutes or has the potential to pollute a water resource or is likely to have a detrimental effect on a water resource in terms of Section 20(1)(a)-(c). A responsible person must take all reasonable measures to contain and minimize the effects of the incident, undertake clean-up procedures, remedy the effect of the incident and take such measures as the catchment management agency may either verbally or in writing direct within a specified time. The catchment management agency may recover all reasonable cost it has incurred from every person responsible jointly and severally. In Lascon Properties (Pty) Ltd v Wadeville Investment Co (Pty) and another 1997 (4) SA 578 (W). The escape of water containing injurious matter from the mine was an issue. The mines and works regulations prohibited the escape of such water without having been rendered harmless. The purpose of the regulation was to benefit the owner of land which might be polluted as a result of the actions of a mining company. The court held that the legislature would not have imposed an obligation to prevent the escape of noxious water without intending that persons harmed are thereby entitled to be compensated by the person permitting the water to escape. The legislature intended to provide a civil remedy to damage caused by a breach of the regulation extending beyond a mere interdict. The law of delict may be used to recover damages caused as a result of polluted water from mining activities.

The National Environmental management Act 107/98 which governs the environment in its totality, entrenches the public trust doctrine as a crucial component of South African environmental governance by providing that "the environment is held in public trust for the people, the beneficial use of environmental resources must serve the public 
interest and the environment must be protected as the people's common heritage in Section 2 (4)(0) of the Act." Section 34(7) provides for vicarious liability of controlling officers of corporation which reads that:

\begin{abstract}
"Any person who is or was a director of a firm at the time of the commission by that firm of an offence under any provision listed in schedule 3 shall himself or herself be guilty of the said offence and liable on conviction to the penalty specified in the relevant law if the offence in question resulted from the failure of the director to take all reasonable steps that were necessary under the circumstances to prevent the commission of the offence: provided that proof of the said offence by the firm shall constitute prima facie evidence that the director is guilty under this sub-section."
\end{abstract}

The Act provides that such manager, agent, employee or director may be so convicted and sentenced in addition to the employer or firm. This provision is important since it applies to any prosecution listed in schedule 3 of the Act (Schedule 3 contain national and provincial legislatures including section 151 (1)(i) and (j) of the NWA. This schedule is important to water pollution in respect of a person who unlawfully and intentionally or negligently commits any act or omission which pollutes a water resource; it targets managers, agents or employee for their act or omission. It provides an incentive to shy away from purposefully or negligently committing an offence because they will be held personally liable regardless of their position in the employment relationship or company. This may consequently stimulate the protection and conservation of the environment especially water resources. Directors, agents and employees of a company are expected to exercise their duty with care and ensure that their actions are not detrimental to the environment and their respective companies.

In Bareki \& Another v Gencor Ltd \& Others 2006 (1) SA 432 (T), the plaintiffs in the matter alleged that between 1976 and1981, the Griqualand Exploration and Finance Co (Pty) Ltd undertook operations to mine asbestos at the Bute Asbestos Mine and caused significant pollution in the mining and surrounding areas by the distribution of asbestos fibres. The remains of mining were still present in the form of asbestos dumps, a beneficiation plant, a mill and a haul road between the mill and beneficiation plant even though the mining activities were discontinued between 1981 and 1985. The plaintiff alleged that this pollution constituted a serious health risk to residents and occupiers of the areas concerned, and a significant threat to the environmental integrity of the region. The plaintiff wanted Gencor and the government (as the owner of the land) to be responsible for rectifying the pollution and or degradation. The plaintiff wanted to rely on the provisions of section 28(12) of The National Environmental Act 107/98. The court's judgement failed to confirm the retrospective application of section 28 of the National Environmental Management Act 107/98.

The basis for the court's finding was the common law presumption against retrospection, linked to the nature of the obligation set out in section 28. The court found that the obligation to take reasonable corrective measures in relation to pollution were strict and possibly even absolute. For this reason, the court held that the legislature could not have intended the obligation to apply retrospectively.

This however has been rendered obsolete by legislative amendments of Act 14/2009. A new section $28(1 \mathrm{~A})$ has been inserted which indicates that the duty defined in section 28(1) - which applies to the actual polluter applies to significant pollution and degradation of the environment that occurred before the commencement of NEMA; that arises or is likely to arise at a different time from the actual activity that caused the contamination, or that arises through an act or activity of a person that results in a change to pre-existing contamination. This can be taken as an expression of clear legislative intent that section28 (1) applies retrospectively.

The Water Service Act 108 of 1997 works in tandem with the NWA. In order to implement its objectives, the Act established several water services institutions being the water service authorities, water service providers, water services intermediaries, water boards and water service committees. The water service authority must give approval in terms of section 6 or 7 of the Act to any person to dispose industrial effluent in any manner approved by the service authority; such water service authority may not unreasonably withhold the approval and may give approval subject to reasonable conditions. This power is important in relation to water pollution; as administrative control of pollution is set to become the principal pollution management mechanism, it is likely that the water authority will attach onerous pollution prevention or waste minimisation provision to its sewage disposal permits (Sampson Deloite \& Touché 2001). The person must respect the reasonable condition attached to the sewage disposal permits, failure to adhere to these may results in the permit being withdrawn thereby effectively preventing the discharge of any trade effluent into the sewage disposal system. In practice, however, industries do not often comply with trade effluent permits and they are not detected due to lack of environmental practitioners to enforce and monitor the application of such permits. Qualified individuals are needed to work in environmental matters and compel companies to comply with trade effluents.

Section 20 of the Health Act Health Act 63 of 77 provides that:

(1) " every local authority shall take all lawful, necessary and reasonably practicable measures- 
(a) to maintain its district at all times in a hygienic and clean condition;

(b) to prevent the occurrence within its district of-

(i) any nuisance;

(ii) any unhygienic condition;

(iii) any offensive condition; or

(iv) any other condition which will or could be harmful or dangerous to the health of any person within its district or the district of any other local authority, or, where a nuisance or condition referred to in subparagraphs (i) to (iv), inclusive, has so occurred, to abate, or cause to be abated, such nuisance, or remedy, or cause to be remedied, such condition, as the case may be;

(c) to prevent the pollution of any water intended for the use of the inhabitants of its district, irrespective of whether such water is obtained from sources within or outside its district, or to purify such water which has become so polluted..."

It enables every local authority to take all lawful, necessary and reasonable practicable measures to prevent the pollution of any water intended for the use of the inhabitants of its district irrespective of whether such water is obtained from sources within or outside its district or to purify such water which has become polluted Section 20 (1)(c). It also gives powers to the Minister to pass regulations in this matter in order to avoid conditions that poses a threat to the population; any person who contravenes or fails to comply with any of its provision including the prevention of water pollution is guilty of an offence.

The holder of reconnaissance permission, prospecting rights, mining permit or retention permit is responsible for any environmental damage, pollution or ecological degradations as result of his or her reconnaissance prospecting or mining operations which may occur inside and/or outside the boundaries of the area to which such rights permit or permission relates (Mineral and Petroleum Resources Development Act 28/02, section 38(1)(e). A drastic measure is made by providing that a director of a company or members of a close corporation are jointly and severally liable for any unacceptable negative impact on the environment including damage, degradation, or pollution purposefully or inadvertently caused by the company or close corporation which they represent or represented. Mining activities may pollute water and have disastrous consequences on the environment. The Minister has made regulations on the use of water for mining and related activities aimed at the protection of water resources (GN 704 in GG 20119 dated 4 June 1999).These regulations contain measures to deal with water pollution that may result from mining activities. They compel every person in control of a mine or its activity to take reasonable measures to prevent waste water or any substance which causes, or is likely to cause pollution of a water resource from entering any water resource, either by natural flow or by seepage. He or she must retain or collect such substance or water containing waste for use, reuse, and evaporation or for purification and disposal in legally appropriate terms. Everyone in the control of a mine or activity must take reasonable measures to design, modify, locate, construct and maintain all water systems, including residue deposits in any area so as to prevent the pollution of any water resource. The regulations provide for offences and penalties against anyone who contravenes any provision of preventing water pollution in mining activities.

\section{Conclusion}

There are ample and sufficient laws in place to tackle and control water pollution. There are also other measures in place to curb water pollution. There is need to ensure that in case of water pollution, the culprit should be made to correct the wrong done and possibly restitution by engaging in cleaning activity to make the water clean and safe. If the culprit is not compliant, sanctions and penalties inherent in various water pollution laws should be invoked in order to make the culprit accountable and allow justice to take its full course.

\section{Recommendations}

The National Water Act has to create a permanent fund to remedy polluted waters, if the offender is unable, or fails to take reasonable and necessary measures, or cannot be found. The Act must include a provision that requires those carrying out activities that might cause pollution to our waters to pay deposits into a fund before commencing with such activities so that if the water is polluted, the deposit can be used to remedy the polluted waters. This is because it would be unfair to expect taxpayers who are not involved in the pollution of the water to contribute to such a fund. If polluted waters are not immediately remedied, they may cause a disastrous effect on the environment, and have far reaching consequences.

The national government is responsible for water in South Africa which means that the other spheres of 
government do not have a part to play in ensuring that the water is preserved. Another broad shortfall of the existing policy framework is that it puts government in a reactionary rather than proactive position, as demonstrated by the pricing structures and enforcement mechanism used to deal with polluters such as the polluter pay principle.

By- laws can be made by a legally established corporate body, such as a district or provincial government and can for example determine the regulation and pollution of local water resources. However by- laws made by lower level institutions cannot contradict those made by higher level institutions.

Political commitment, efficient administrative implementation and enforcement and adequate compliance with the provisions of the system may ultimately result in achieving the overall objectives of the Act which are inter alia to ensure that the nation's water resources are protected, used, developed, conserved, managed and controlled alongside sustainable imperatives. If politicians allow the law to be applied fairly without favour or prejudice to those who commits environmental crimes irrespective of their political affiliations or social standing, the problem can be curbed.

Publicity orders are recommended to be included in South African legislation dealing with water pollution. If an environmental crime such as water pollution has been committed, the responsible person must be forced to publicise such offence, its environmental consequences, penalties and other orders that may damage the prestige of the offender and can have a significant impact on deterring persons from polluting water. The orders are made to the persons affected by or interested in, the conviction and may appear in the offender's annual report. Many corporations are sensitive about their prestige and will ensure that the offence does not reoccur. Only courts may authorise publicity orders.

There is a need to provide environmental education to offenders, employees and contractors. Sometimes environmental offences are committed as a result of ignorance by the persons concerned. To rectify this situation, the catchment management agency and other water pollution institution or court may order the offender to attend, or cause employees or contractors to attend, a specified training course that deals with water pollution. The offender can also organise a training course for his or her employees. Public education can also play an important role in educating and making ordinary people to be aware of the dangers of water pollution and the environment so that people can understand and value water and take action to improve their local rivers and the environment around them.

There is a shortage of personnel in the field of environmental law specifically in water pollution issues. The police do not have the necessary skills and expertise to deal with environmental crimes. Thus when matters involving environmental crimes are taken to court, they are not ready to be proceeded with. This result in most of them ending up being withdrawn or the perpetrators are acquitted on technicalities. The Department of Justice should include environmental courses in the training programmes of prosecutors and magistrates. Designated courts with prosecutors and magistrates should be allocated to environment and water pollution matters so that they can build expertise in this field.

The South African statute prohibits any person from discharging trade effluent into a water resource unless the discharger has a permit and respect its conditions. Failure to comply with conditions in a permit is a criminal offence. The statute focuses on the intention or negligence of the offenders and provides different punishment for water polluters. South Africa can criminalise the offenders knowing the endangerment of people's lives by holders of permits who knowingly places another person in imminent danger of death or serious bodily injury by ignoring the conditions of their permits.

\section{References}

Albert PJ, Werhane P, Rolph T 2014. Global Poverty Alleviation: A Case Book. From http://link.springer.com/book/10.1007/978-94-0077479-7. (Retrieved on 8 February, 2014).

Aller L, Lehr JH, Petty R, Bennett T 1987. Drastic: A standhrdized system to evaluate ground water pollution potential using hydrugedlugic settings. From http://rdn.bc.ca/cms/wpattachments/wpID3175atID5999.pdf. (Retrieved on 8 February, 2014).

Annenberg L 2010. The habitable planet, unit 8: water resources. From available:www.leaner.org/courses/envsci/unit/pdfs/unit 8. Pdf. Accessed 20/05/14. (Retrieved on 16 June, 2013).

Ashbolt NJ 2004. Microbial contamination of drinking water and disease outcomes in developing regions. Toxicology, 198(1-3): 229-238.

Bakker K 2007. The "Commons" Versus the "Commodity": Alter-globalization, Anti-privatization and the Human Right to Water in the Global South. Antipode. 39(3): 430-455.

Batterman S, Eisenberg J, Hardin R, Kruk ME, Lemos MC, Michalak AM, Mukherjee B, Renne E, Stein H, Watkins C,. Wilson ML 2009. Environmental Health Perspectives, 117(7): 1023-1032.

Blaine S 2012. Carolina's polluted water highlights growing problem in S.A. From www.Ihr.org.za/news/2012 Carolina's- polluted waterhighlights-growing- problem- in sal. (Retrieved on 22 May, 20/14).

Bond P, Desai A 2011. Durban's water wars, sewage spills, fish kills and blue flag beaches. From http://ggjalliance.org/es/system/files/ Bond\%20Durban's\%20Climate\%20Gamble\%20UNISA\%20Press.pdf\#page=83. (Retrieved on 12 October, 2013). 
Brunner P, Cook PG, Simmons CT 2011. Disconnected Surface Water and Groundwater: From Theory to Practice. Groundwater, 49(4): 460-467.

Burchi S, 2012. A comparative review of contemporary water resources legislation: trends, developments and an agenda for reform. Water International. 37(6): 613-627.

Chapman DV 1996. Water quality assessments: a guide to the use of biota, sediments and water in environmental monitoring. From http://www.who.int/water_sanitation_health/resourcesquality/watqualassess.pdf. (Retrieved on 28 July, 2014).

Dales JH 2002. Pollution, property \& prices: an essay in policy-making and economics. Edward Elgar Publishing Ltd, Cheltenham UK

Davis DL 2003. When smoke ran like water: Tales of environmental deception and the battle against pollution. Basic Books, New York, USA.

Drinan JE, Spellman F 2012. Water and wastewater treatment: a guide for the non-engineering professional. CRE Press, New York, USA.

Ewart TI 2011. Acid mine drainage in the Gauteng Province of South Africa: a phenomenological study on the degree of alignment between stakeholders concerning a sustainable. From http://scholar.sun.ac.za/handle/10019.1/17978. (Retrieved on 29 December, 2013).

Falkenmark M, Rockström J 2004. Balancing water for humans and nature: the new approach in ecohydrology. Earthscan, London, UK.

Feris L 2012. Public Trust Doctrine and Liability for Historic Water Pollution in South Africa. Law Environment \& Development Journal, 8:1-11.

Ganoulis J 2008. Engineering risk analysis of water pollution: probabilities and fuzzy sets. VCH Publishers, New York, USA.

Grossman M R 2006. Agriculture and the polluter pay principle. From www.ejcl.org/113/article113-15.pdf. (Retrieved on 21 January, 2014).

Harte J, Holdren C, Schneider R, Shirley C 1991. Toxics A to Z: A guide to everyday pollution hazards. University of California Press, Oxford England.

Helmer R, I Hespanhol, W Supply, SC Council 1997. Water pollution control: a guide to the use of water quality management principles. http://www.who.int/ADA29D3F-FB15-4A37-982F. (Retrieved on 29 January, 2014).

Hines N W 1966. Nor Any Drop to Drink: Public Regulation of Water Quality Part I: State Pollution Control Programs. Iowa Law Review, 52: 186-197.

Hogan MC 2013. Water pollution. www.Eoearth.org/view/article/156920/accessed:21/05/14. (Retrieved on 16 June, 2014).

Hollar S 2011. Poisoning Planet Earth: Pollution and Other Environmental Hazards. Britannica Educational Publishing, New York, USA.

Hunt CE 2007. Thirsty planet: Strategies for sustainable water management. Academic Foundation, New Delhi, India.

Irwin FH 1992. Integrated Framework for Preventing Pollution and Protecting the Environment. Environmental Law, 2:1-12.

Glazewski J 2005. Environmental Law in South Africa 2ed 2005.

Järup L 2003. Hazards of heavy metal contamination. British medical bulletin, 68 (1): 167-182.

Jeffries M D 1990. Fresh water ecology: principles and applications. Belhaven Press, London, UK.

Kanamugire JC 2008. Offences and penalties for water pollution in South Africa: a comparative analysis of South African, British, American and Australian legislation. From http://thembosdev.com/beginning\%20_dissertation_kinamugire08.pdf. (Retrieved on 12 September, 2013).

Kettlewell U 1992. Answer to Global Pollution - A Critical Examination of the Problems and Potential of the Polluter-Pays Principle. Colorado Journal International Law \& Policy, 3: 429-441.

Kidd M 2009. South Africa: The Development of Water Law, The Evolution of the Law and Politics of Water. pp 87-104.

Kirda C, Kanber R 1999. Water, no longer a plentiful resource, should be used sparingly in irrigated agriculture. Kluwer Academic Publishers, Dordretch, The Neitherlands.

Kotzé LJ 2010. Phiri, the plight of the poor and the perils of climate change: time to rethink environmental and socio-economic rights in South Africa? From http://e-elgar.metapress.com/index/M76330617404W735.pdf. (Retrieved on 16 November, 2013).

Kotze LJ, Bosman C 2006. A legal analysis of the proposed waste discharge system in terms of the South African environmental and water law framework. Obiter, 27(1): 128-145.

Kreamer DK, Usher B 2010. Sub-Saharan African Ground Water Protection-Building on International Experience. Groundwater, 48(2): 257-268.

Malmqvist B, Rundle S 2002. Threats to the running water ecosystems of the world. Environmental conservation, 2: 134-153.

Manual T 2008. Conflict Resolution and Negotiation Skills for Integrated Water Resources Management. From http://www.vipp.es/ biblioteca/CC_3010.pdf. (Retrieved on 29 May, 2014).

Mason CF 1990. Biological aspects of freshwater pollution: In green pollution book

Mason G, Clubb R, Latham N, Vickery S 2007. Why and how should we use environmental enrichment to tackle stereotypic behaviour? Applied Animal Behaviour Science, 102(3-4): 163-188.

Nash JR 2000. Too Much Market: Conflict between Tradable Pollution Allowances and the Polluter Pays Principle. Harvard Environmental Law Review, 24:465:476.

Oberholster PJ, Botha, AM, Cloete, TE 2008. Biological and chemical evaluation of sewage water pollution in the Rietvlei nature reserve wetland area, South Africa. Environmental Pollution. 156 (1) 184-192.

Otieno FAO, Ochieng GMM 2007. Water management tools as a means of averting a possible water scarcity in South Africa by the year 2025. Water SA, 30(5): 120-124.

Palmer MA, Richardson DC 2009. Provisioning services: a focus on freshwater. The Princeton Guide to Ecology. From 
https://faculty.newpaltz.edu/davidrichardson/files/Palmer2009-PrincetonGuideEcology-FreshwaterEcosystemServices.pdf. (Retrieved on 2 October, 2013).

Postel S, Richter B 2003. Rivers for life: managing water for people and nature. Island Press, UK, London

Postel SL 2000. Entering an era of water scarcity: the challenges ahead. From http://www.esajournals.org/doi/abs/10.1890/1051(Retrieved on 18 February, 2014).

Ritter L, Solomon K, Sibley P, Hall K, Keen P, Mattu G, Linton B 2002. Sources, pathways, and relative risks of contaminants in surface water and groundwater: a perspective prepared for the walkerton inquiry, Journal of Toxicology and Environmental Health, , 65(1): 1-142.

Sampson Deloite \& Touché 2001. Introduction to a legal framework to pollution management in South Africa. WRC Report No TT 1949/01 March 2001 page 102.

Scanlon J, A Cassar, N Nemes 2004. Water as a human right? IUCN Publications, Cambridge, UK.

Schaeffer A 2012. Prevention is better than cure. .Edward Elgar Publishing Ltd, Cheltenham UK.

Stein R 2004. Water Law in a Democratic South Africa: A County Case Study Examining the Introduction of a Public Rights System. Texas Law Review, 83 :2167-2178.

Stein R 2005. Symposium of waterbanks, piggybanks, and bankruptcy: changing directions in water law: vii. transformative politics, altrnative policy regimes: water law in a democratic South Africa. Texas Law Review, 83: 2167-2174.

Steven L 1989. Humphreys SL 1989. Enemy of the People: Prosecuting the Corporate Polluter as a Common Law Criminal, American University Law Review, 39:311-321.

Tran KC, Euan J, Isla ML 2002. Public perception of development issues: impact of water pollution on a small coastal community. Ocean \& Coastal Management, 45(6-7): 405-420.

UNRISD 2003. United Nations Research Institute for Social Development XVI Salle, G Palais .Corporate Social Responsibility and Development: Towards a New Agenda? From http://www.unrisd.org/UNRISD/website/document.nsf/d. (Retrieved on 2 September, 2013).

Shiva V 2002. Water Wars. Privatization, Pollution and Profit. From http://courseresources.mit.usf.edu/sgs/ang6469/canvas/module_7 /read/The_Sacred_Waters.pdf . (Retrieved on 12 October, 2013).

Vörösmarty CJ, Green P, Salisbury J, Lammers RB 2009. Global water resources: vulnerability from climate change and population growth. Science, 289(5477): 284-288. 